\title{
CASH CONVERSION CYCLE SENSITIVITY BY MODERATING ROLE OF EXCHANGE RATES VOLATILITY ON FIRM'S FINANCIAL PERFORMANCE
}

\author{
Sarfraz HUSSAIN ${ }^{1 *}$, Asan ALI GOLAM HASSAN (i)2, Abdul QUDDUS(1) 3 , \\ Muhammad RAFIQ ${ }^{4}$, Van CHIEN NGUYEN (1) 5 \\ 1, 2, ${ }^{4}$ Azman Hashim International Business School, Universiti Teknologi Malaysia, Kuala Lumpur, Malaysia \\ ${ }^{3}$ Department of Finance \& Accounting, Faculty of Management and Economics, \\ Tomas Bata University in Zlín, Zlín, Czech Republic \\ ${ }^{5}$ Thu Dau Mot University, Thu Dau Mot City, Vietnam
}

Received 12 July 2020; accepted 22 March 2021

\begin{abstract}
The cycle of cash conversion relates to the time spread between the value of cash paid for purchases and the cash receipt from turnover. Using the State Bank of Pakistan data, this study introduces the direct and moderating role of the exchange rate, effective through the efficient execution of the cash conversion cycle between Pakistani 302 manufacturing companies from 1999-2015. Using the fixed effect as the static panel model and system GMM as a dynamic panel, it is observed that the exchange rate plays an authoritative moderating role between the cash conversion cycle and the financial performance. Results of the investigation have shown that in static panel analysis with the cash conversion period, the exchange rate has a positive and substantial moderating effect on return on assets and return on equity whereas that ER has a major negative impact on return on assets and return on equity using dynamic panel data analysis GMM. The issue of endogeneity in the static panel is addressed using the advanced approach of the standard error of the panel correction standard error method that changed the position of the significance of the moderator variable. Observers, therefore, intend to evaluate the fluctuations in the exchange rate as one of the variables of the financial output moderator in the context of current metrics such as asset's returns, equity's returns and gain more practical expression within their investigated results.
\end{abstract}

Keywords: return on assets, exchange rate, return on equity, cash conversion cycle, profitability.

JEL Classification: G31, G34.

\section{Introduction}

The cash conversion cycle (CCC) is equal to the duration the inventory is sold and the time it takes until accumulated releases for the company's payout. The cash conversion cycle, in other terms, is the resultant production of three elements, most importantly the company account receivable in days, including inventory turnover in days, subtracting payable turnover in days. This indicates the days in which the cash of a company is tied up in the business process. The CCC apprehends one of the key features of a firm's process, that is, it identifies that the four corporate nucleus exercises (purchasing or manufacturing, selling, procurement, and payment) flow into a working capital company. This is a commonly used criterion for determining the effectiveness of the management of a company and the need for outside financing (Hong, 2020).
This research investigates the effect of the exchange rate on the financial performance of the enterprise on cash conversion cycle CCC management patterns. Normally and typically, corporate practice is that they want to strengthen the CCC, where the key emphasis is to delay long-term payments and recover from receivables shortly. In this phase, few funds can be used to increase their operating activities and make more profit from the cycle of business operations. But if the domestic currency exchange rate becomes very unpredictable, then finance managers need to handle the existing business cycle in compliance with forex market standards. It was the Pakistani rupee phenomenon that has very high volatility and its international transactions, as well as local transactions, could not be handled by the company. Local business units face a high degree of price rivalry in the local market and even in the international market in such a situation. It takes an

${ }^{*}$ Corresponding author. E-mail: mianfraz1@gmail.com 
hour for company finance managers to fully update their forex market details regularly to deal with foreign traders to handle the situation, so they can use hedging strategies with new terms and conditions. Up to now, this gap has existed in the international business finance literature and no research has identified where this phenomenon has been addressed. This uncontrollable problem, strictly related to international (receivable and payable) contracts, is disrupted by the instability of the exchange rate and may not be able to survive in weaker economies due to such an unpredictable financial situation. Specific CCC, companies finance their working capital as much as possible for short-term assets and short-term loan firms perform poorly through times of the financial crisis (Cheng et al., 2019).

In the modern business world, success is only feasible if a company has sufficient monetary means to meet its long-term investments and small-period obligations, among other things. A succession of the cash conversion cycle is just as important for controlling long-term business financing as a productive use of fixed assets is only possible if a substantial amount of CCC in the organization changes not individual short-term business performance but also long-term financial sources, i.e., maximizing firm value (Boisjoly et al., 2020).

Maintaining the aspired level of CCC capacity makes strong managers take appropriate arrangements for working capital investment and small-time funding. Such determinations remain crucial points for CCC management. CCC has grown one of the major concerns in companies where it is difficult for different financial managers to differentiate CCC's essential hacks and settle at the optimum level of CCC. This one exists the periods of receivables plus the number of inventories of days and the period of payable for subtraction. The longer the CCC, the higher the assets that are in WC. Accordingly, the situation is important to discover a proper plus advance achievement (result) portion which clearly and straightly describes the influence of the companies' WC productivity (Sawarni et al., 2020). Several investigations identified the CCC's influence on the business' financial achievements (Seth et al., 2020). These investigations addressed an overall return on assets, equity return (ROE), as a proxy for the profits of companies.

In the current research, the prevalence of this research is manifold. First, this is the basic research which offers the exchange rate for most of our understanding of option, i.e., the real effective exchange rate (REER) remains used as the moderator between CCC and financial performance. The connections between CCC and financial performance of the firms. Second, where evidence in favour of this indirect effect on areas of Pakistani firms has been taught, it can usually be employed in firms in any other country. Finally, CCC $\times$ ERs are easy to measure and are therefore very useful. Pakistan has been adopting a marketbased flexible exchange rate regime since May 1999. For all foreign exchange collections and transfers, both in the industry and government, the inter-bank rate is applied.
The foreign exchange rate is calculated by the supply and demand conditions of the forex market in the domestic financial system (Ha \& Hoang, 2020). Rupee is very frequently volatile in Pakistan and very high shocked can be observed throughout the observed period in exchange for USD, it can become volatile from 98 to 128 wavelength exceeded from 30 repeat. Traditional research concentrated on the effects of CCC on asset's return and equity's return, but the major portion of foreign receivables and payable (contracts) were not considered to be disturbed due to ER, and this was the broad distance between CCC and ROA and ROE to find the moderating effect of ER. To research and refine advances in functional and financial measurement methods and to analyse the implications of these developments for improving business transactional assessment. Interest in the intersections of this area is not new. Accepted by calls for assessments who can be better informed regarding cash owing from receivable and payable, a range of educational researchers have demonstrated the possible benefits of integrating modern international finance expertise and can set industrial transaction management methods and techniques that help financial managers cope with exchange rate movement phenomena and their system shocks. This research spreads real works by developing evidence of CCC's influence by ER volatility as moderating effect on financial means of performance.

The rest of this paper is structured with a sample of papers on CCC as mentioned in-depth in Part 2. Part 3 provides the framework for the development of the performance measures to explore the moderating role of ER (REER) with CCC in the financial performance of companies. The preliminary results will be presented in part 4 where the CCC administration will expand on the results of the study due to the efficient business performance. Finally, Part 5 ends and discusses broad research capacity.

\section{Review of literature}

\subsection{Cash conversion cycle and firm financial performance}

Normally believed that CCC produces a significant impact on the financial habit of the business, which is Return on Equity (ROE) and Return on Assets (ROA). Both ratios were employed as a proxy for profitability in this study. Concentrating on the cash conversion cycle through administrative control of receivables, stock inventories, and payables. The CCC provides for liquidity and profitability creation (Hossain, 2020). Additionally, inventory stock management surely requires liquidity from management to maximize profitability. Examining the effect of the CCC decision on gross profit (GP) as a measure of firm performance. It comes from an optimistic partnership between the CCC and the GOP. Numerous investigations, however, have initiated an adverse link between the CCC and firm monetary performance (Doan \& Bui, 2020). Shah (2019) examined the impact on ROA and ROE of account receivable turnover, inventory turnover, account payable 
in days, and cash conversion processes and initiated an adverse relationship between CCC and its components. The results revealed an unfavourable association between ROA and the cash conversion cycle. Notably, the difference in Tobin's Q model shows that CCC had no meaningful impact on companies' net worth (Sawarni et al., 2020). Because specific historical studies have observed and show that the management of working capital by the organization (which results in a reduced cash conversion cycle) leads to increased accounting efficiency, this work argues that:

Hypothesis 1. The Pakistani manufacturing firms listed have substantial adverse relation between the CCC and return on asset.

A result of CCC's conventional approach to accounting-based performance measures, they cannot answer the problem of exactly how CCC can increase corporate profit. Many related output deals should stay like removing the violation about the interest of CCC and the firm's performance. A large portion of businesses operational finances are related to the three components of the CCC (accounts receivables, inventories, and accounts due). It will result in a liquidity deficit that deals with financial management, borrowing and debt-related expenses (Högerle et al., 2020).

\subsection{Exchange rate as macroeconomic factor and firm performance}

Many experiential studies have investigated the effect of these influences on the use of company results (accounting and market-based measures) using several methods and strategies. Macroeconomic factors have been stated to have a substantial influence on sustainable firm production in a broad variety of ways (Doan \& Bui, 2020). Exchange rates (REER) are a key macroeconomic indicator in literature. It raises production prices, however, which can have an adverse effect on sales. If the net influence of these results is negative, then productivity will decrease and demonstrated performance. Experimental experiments have found that ER (REER) has a significant effect on the cost of supply, suggesting that higher ER (REER) rates decrease revenue. Oseifuah (2016) acknowledged that ER (REER) is closely associated (measured by Return on assets) with reliable efficiency. However, this partnership is essentially and fluctuates depending on its strategic, political, and financial constraints. There is a favorable and surprising relation between the CCC and the ER, the value of the coefficient, a rise in the exchange rate affecting the CCCs of the company's (Widyastuti et al., 2017).

A few studies investigated this issue by examining ROE and ROA as variables of response regarding ER as moderating variable. Therefore, this research investigates the interaction impact of ER on ROA and ROE by multiplying ER with CCC. Since there is no strong evidence for a relatively large increase in income and expenses, and there is a combination of practical testimony about the impact of ER (REER) on bookkeeping and economic performance, there is no guidance for this association that you can imagine. Based on this situation the assumptions were made as follows:

Hypothesis 2. There is indeed a strong link regarding ER (REER) and the return on assets to firm's financial performance.

\subsection{ER (REER) moderating position as macro- economic variables}

The state of the CCC shifts considerably during periods of volatile in ER (REER), expecting an answer with appropriate policies to maintain balance. It must be achieved through ER (REER) changes, a spike in working capital. In addition, as the ER levels decrease, sales decrease, which in essence decreases the revenue of the organisation and thus lowers the profit margin. Therefore, businesses need to increase their sales credit period to counterbalance the decrease in the profit margin that results in a higher CCC (Khan et al., 2020). In effect, the ER can have a negative impact on purchasing power clients, who eventually affect the lending practices of firms and the collection times of bill receivables. These days, businesses struggle with higher CCC as their inventory stocks are locked up and their production is not sufficient, and the receivables are not identified. It was found out that exchange-rate volatility increases the expense of selling goods. Accordingly, businesses respond by stopping and increasing stock inventories, account receivables, rising bills payable, the result of which is to prolong the CCC duration (Aytac et al., 2020).

Table 1. Empirical literature review "relationship of Cash conversion cycle with firm performance"

\begin{tabular}{|l|l|l|l|}
\hline \multicolumn{1}{|c|}{ Authors } & \multicolumn{1}{|c|}{ Sample and Methods } & \multicolumn{1}{c|}{ Findings } & $\begin{array}{c}\text { Use of Moderator } \\
\text { variable }\end{array}$ \\
\hline (Iqbal et al., 2020) & $\begin{array}{l}\text { Period from 2014 to 2018 } \\
\text { were included in the analysis. } \\
\text { Population included 43 food } \\
\text { and beverage firms listed on the } \\
\text { NSE stock exchange. }\end{array}$ & $\begin{array}{l}\text { The study findings indicate that the cash conversion } \\
\text { cycle tends to have a strong negative relationship } \\
\text { with profitability measured by ROA. }\end{array}$ & No \\
\hline (Seth et al., 2020) & $\begin{array}{l}\text { Sample of 563 Indian production } \\
\text { firms engaged in export activities, } \\
\text { panel regression (fixed effects) was } \\
\text { employed for the period between } \\
\text { 2008 to 2018. }\end{array}$ & $\begin{array}{l}\text { Industry-wise results have shown a strong } \\
\text { profitability connection with the cash conversion } \\
\text { cycle }\end{array}$ & No \\
\hline
\end{tabular}


End of Table 1

\begin{tabular}{|c|c|c|c|}
\hline Authors & Sample and Methods & Findings & $\begin{array}{l}\text { Use of Moderator } \\
\text { variable }\end{array}$ \\
\hline (Ujah et al., 2020) & $\begin{array}{l}\text { Non-utility and non-financial } \\
\text { companies for the years } 1980 \text { to } \\
\text { 2016, this research mainly employs } \\
\text { a panel fixed-effect management } \\
\text { system for company-year and } \\
\text { company-industry. }\end{array}$ & $\begin{array}{l}\text { The authors find the association between } \\
\text { managerial talent and CCC to be positive and } \\
\text { significant. The results indicate that talented } \\
\text { managers have a higher cash conversion cycle }\end{array}$ & No \\
\hline (Moussa, 2019) & $\begin{array}{l}\text { A panel data analysis was used } \\
\text { for } 68 \text { listed Egyptian companies } \\
\text { during } 2000-2010 . \text { GMM is used } \\
\text { to test the validity of the study } \\
\text { assumptions. }\end{array}$ & $\begin{array}{l}\text { The findings also showed a very important positive } \\
\text { correlation between company performance and } \\
\text { CCC in all models. }\end{array}$ & No \\
\hline$(\mathrm{Le}, 2019)$ & $\begin{array}{l}\text { A panel data collection of } 497 \\
\text { companies covering the } 2007 \text { to } \\
2016 \text { era is used. Using the panel } \\
\text { data approach that includes firm } \\
\text { and the year fixed effect model } \\
\text { regression analysis. }\end{array}$ & $\begin{array}{l}\text { A significantly negative relationship between net } \\
\text { working capital and firm valuation, profitability, } \\
\text { and risk. }\end{array}$ & No \\
\hline (Ren et al., 2019) & $\begin{array}{l}\text { For the period } 2010 \text { to } 2017, \\
\text { the analysis applies two-way } \\
\text { fixed effect regression models } \\
\text { to a sample of Chinese listed } \\
\text { manufacturing firms. }\end{array}$ & $\begin{array}{l}\text { A negative association between CCC and company } \\
\text { performance is shown by the findings. }\end{array}$ & No \\
\hline $\begin{array}{l}\text { (Q. Lin \& X. Lin, } \\
\text { 2020) }\end{array}$ & $\begin{array}{l}\text { U.S. market return predictability } \\
\text { is empirically assessed based on } \\
\text { an aggregate measure constructed } \\
\text { from the } 1976-2018 \text { bottom-up } \\
\text { firm-level cash conversion period } \\
\text { (CCC). Our sample includes all } \\
\text { common stocks from the CRSP } \\
\text { data set with share codes } 10 \text { or } \\
11 \text { and those listed on the NYSE, } \\
\text { AMEX, and NASDAQ. }\end{array}$ & $\begin{array}{l}\text { In addition, the aggregate CCC will forecast returns } \\
\text { from the cross-sectional stock portfolio sorted by } \\
\text { scale, value, momentum, CCC at the company } \\
\text { level, and industry, and produce large equivalent } \\
\text { assurance gains associated with a market-timing } \\
\text { strategy. }\end{array}$ & No \\
\hline (Chang, 2018) & $\begin{array}{l}\text { By taking companies from } \\
\text { different nations as samples, this } \\
\text { conducts a global empirical study } \\
\text { of the relationship between the } \\
\text { cash conversion cycle (CCC) and } \\
\text { corporate results. }\end{array}$ & $\begin{array}{l}\text { It finds a negative relationship between the CCC } \\
\text { and the company's profitability. }\end{array}$ & No \\
\hline $\begin{array}{l}\text { (Zeidan \& Shapir, } \\
\text { 2017) }\end{array}$ & $\begin{array}{l}\text { Listed company in Brazil, MRV. } \\
\text { Improvements in operations } \\
\text { reduced CCC from } 508 \text { days in } \\
2012 \text { to } 351 \text { days in } 2015 \text {, lowering } \\
\text { requirements for working capital } \\
\text { by US } \$ 1.02 \text { billion. }\end{array}$ & $\begin{array}{l}\text { The findings indicate that CCC management, } \\
\text { which controls the impact on operating margins, } \\
\text { contributes to higher stock prices and profitability } \\
\text { and improved cash flow. }\end{array}$ & No \\
\hline $\begin{array}{l}\text { (Dalci \& Ozyapici, } \\
\text { 2018) }\end{array}$ & $\begin{array}{l}\text { The data set was requested from } \\
\text { the ORBIS, including the period } \\
\text { between } 2008-2016.52 \text { hospitals } \\
\text { with } 468 \text {. The leverage moderates } \\
\text { the relationship between CCC and } \\
\text { profitability. }\end{array}$ & $\begin{array}{l}\text { Lengthening of CCC increases profitability for } \\
\text { hospitals with low leverage. The results also show } \\
\text { that lengthening CCC worsens the profitability for } \\
\text { hospitals with high leverage. }\end{array}$ & $\begin{array}{l}\text { Leverage as } \\
\text { Moderates in } \\
\text { between cash } \\
\text { conversion } \\
\text { cycle and firm } \\
\text { profitability } \\
\end{array}$ \\
\hline $\begin{array}{l}\text { (Boisjoly et al., } \\
\text { 2020) }\end{array}$ & $\begin{array}{l}\text { The Center for Research on } \\
\text { Securities Prices and S\&P's } \\
\text { Compustat collect data } \\
\text { companies available for the } \\
\text { period 1990-2017. Standard Least } \\
\text { Squares (OLS) regressions with } \\
\text { the left-hand working capital } \\
\text { metric and separate right-hand } \\
\text { management metrics are the main } \\
\text { methodology used in science. }\end{array}$ & $\begin{array}{l}\text { The cash conversion cycle was found to have a } \\
\text { major and adverse relationship with Tobin's Q or } \\
\text { firm financial performance. }\end{array}$ & No \\
\hline
\end{tabular}




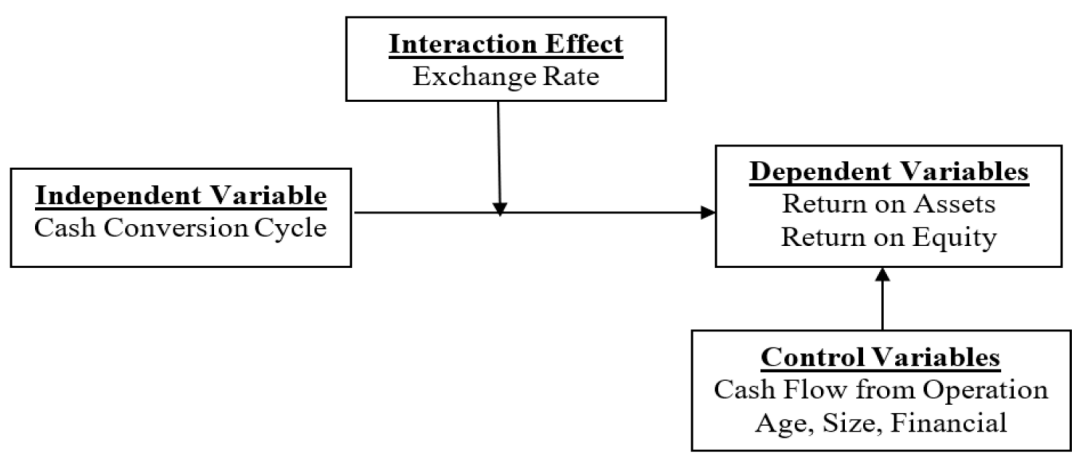

Figure 1. Conceptual framework (source: authors)

ER (REER) supports an increase in the cost of manufacturing the product, which negatively contributes to the CCC efficiency (Kumaraswamy, 2016). In the era of ER volatility, organizations may face liquidity constraints that detrimentally damage the company to meet short-term commitments, leading to a longer CCC period (Onchangwa, 2019). A few experiments have demonstrated a major impact of ER (REER) on working capital. Observed CCC's influence on working capital levels, using synthetic system modeling aside from macroeconomic determinants. Some findings revealed that, although such results are not significant, ER affects the CCC and the working capital. Furthermore, Williams (2018) observed that CCC is like CCC but its effect was not significant. This study shows that although the ROA and ROE arranged by CCC have a straight impact, ER (REER) can moderate those associations. Where ER (REER) is small, companies face higher $\mathrm{CCC}$ and more consistent results, the following is accurate global proof. Here we present the following hypotheses:

Hypothesis 3. ER (REER) undermines the unfavorable influence of the CCC on the return on assets to listed Pakistani firms.

In Figure 1 explain the conceptual framework of the study clearly. Where the roadmap of the current study examined the direct relationship of CCC with moderating role of ER with firm's financial performance. It also shows the effect of some control variable as well.

\section{Data and methodology}

\subsection{Sample}

The model studied included 302 and 4898 observations registered Pakistani businesses working in the manufacturing sector of Pakistan. Sample was selected based on availability of data or using the convenient data sampling techniques, Aron and Maneja (2020) consist of manufacturing firms those have data on receivable and payable are the basic components of the CCC. All nominated companies are registered on the Karachi stock exchange (KSE). The selected sample describes 17 years from 2002 to 2018 and that the statistics were gathered from the State Bank of Pakistan's Department of Statistics. In addition, the World Bank data was used to capture all economic data.

\subsection{Empirical model}

ROA and ROE are the accounting-based output metrics, CCC is used as an explanatory variable. Furthermore, its use cash flow from operation, age, and size as control variables. The term error also defines the variance of dependent variables not defined by the exogenous factor in the models. Ultimately, to succeed in the difficulties of serial correlation and heteroskedasticity, a standard panel correction error regarding the linear regression assessment is applied. ER (REER) the macroeconomic factors are individually included in various regression models to detect the direct effect of macroeconomic upon performance. Estimates are calculated using the following equations:

$$
\begin{aligned}
& R O A_{i t}=\beta_{i t}+\beta_{1}\left(C C C_{i t}\right)+\beta_{2}\left(C F O_{i t}\right)+\beta_{3}\left(E R_{i t}\right)+ \\
& \beta_{4}\left(A G E_{i t}\right)+\beta_{5}\left(\text { Size }_{i t}\right)+\beta_{6}\left(F L_{i t}\right)+\varepsilon_{i t} ; \\
& R O E_{i t}=\beta_{i t}+\beta_{1}\left(C C C_{i t}\right)+\beta_{2}\left(C F O_{i t}\right)+\beta_{3}\left(E R_{i t}\right)+ \\
& \beta_{4}\left(A G E_{i t}\right)+\beta_{5}\left(\text { Size }_{i t}\right)+\beta_{6}\left(F L_{i t}\right)+\varepsilon_{i t} .
\end{aligned}
$$

\section{Nonlinear static regression model where exchange rate used as interaction (moderator) variable}

The ER(REER) of the macroeconomic variable and its interaction factors are presented individually in separate regression models to uncover the moderating function (interaction effects) of the macroeconomic element and produce strong results. The figures for the inquiry are described using the following equation:

$$
\begin{aligned}
& R O A_{i t}=\beta_{i t}+\beta_{1}\left(C C C_{i t}\right)+\beta_{2}\left(C F O_{i t}\right)+\beta_{3}\left(E R_{i t}\right)+ \\
& \beta_{4}\left(A G E_{i t}\right)+\beta_{5}\left(\text { Size }_{i t}\right)+\beta_{6}\left(F L_{i t}\right)+\beta_{7}\left(E R \times C C C_{i t}\right)+\varepsilon_{i t} ; \\
& R O E_{i t}=\beta_{i t}+\beta_{1}\left(C C C_{i t}\right)+\beta_{2}\left(C F O_{i t}\right)+\beta_{3}\left(E R_{i t}\right)+ \\
& \beta_{4}\left(A G E_{i t}\right)+\beta_{5}\left(\text { Size }_{i t}\right)+\beta_{6}\left(F L_{i t}\right)+\beta_{7}\left(E R \times C C C_{i t}\right)+\varepsilon_{i t},
\end{aligned}
$$

wherever $I=1 \ldots 302)$ is the intercept for each company, $t$ $(t=2002-2018)$ characterizes the year under review and $\beta$ is the coefficients for each regressor vector, including the disruption era. Various approaches will be applied to examine the examined static panel models and dynamic 
panel model (Alipour et al., 2019) Pooled Ordinary Least Squares, Random Effects, Fixed Effects with n firm-specific intercepts. Eventually, to solve autocorrelation and heteroskedasticity problems regression equation models used in specific regression with two-step GMM which needed changes to the estimated model. Column 4 th regression model used for normal Panel Correction Standard Error (PCSE).

\subsection{Dynamic Panel Model}

Many companies, banks, economies, and financial services are character-driven problems, which use data panel structures to focus on changes. It is crucial to enable dynamics for the constant evaluation of certain parameters in the primary phase. The dynamic relations are represented through the carriage with the explanatory variables of a lagged dependent variable, that is

$$
\begin{aligned}
& R O A_{i t}=\beta_{i t}+\beta_{1}\left(C C C_{i t}\right)+\beta_{2}\left(C F O_{i t}\right)+\beta_{3}\left(E R_{i t}\right)+ \\
& \beta_{4}\left(A G E_{i t}\right)+\beta_{5}\left(\text { Size }_{i t}\right)+\beta_{6}\left(F L_{i t}\right)+\mu_{i t} ; \\
& R O E_{i t}=\beta_{i t}+\beta_{1}\left(C C C_{i t}\right)+\beta_{2}\left(C F O_{i t}\right)+\beta_{3}\left(E R_{i t}\right)+ \\
& \beta_{4}\left(A G E_{i t}\right)+\beta_{5}\left(\text { Size }_{i t}\right)+\beta_{6}\left(F L_{i t}\right)+\mu_{i t} .
\end{aligned}
$$

The nonlinear dynamic model with exchange rate as interaction (moderator) effect

$$
\begin{aligned}
& R O A_{i t}=\beta_{i t}+\beta_{1}\left(C C C_{i t}\right)+\beta_{2}\left(C F O_{i t}\right)+\beta_{3}\left(E R_{i t}\right)+ \\
& \beta_{4}\left(A G E_{i t}\right)+\beta_{5}\left(\text { Size }_{i t}\right)+\beta_{6}\left(F L_{i t}\right)+\beta_{7}\left(E R \times C C C_{i t}\right)+\mu_{i t}
\end{aligned}
$$

$$
\begin{aligned}
& R O E_{i t}=\beta_{i t}+\beta_{1}\left(C C C_{i t}\right)+\beta_{2}\left(C F O_{i t}\right)+\beta_{3}\left(E R_{i t}\right)+ \\
& \beta_{4}\left(A G E_{i t}\right)+\beta_{5}\left(\text { Size }_{i t}\right)+\beta_{6}\left(F L_{i t}\right)+\beta_{7}\left(E R \times C C C_{i t}\right)+\mu_{i t} .
\end{aligned}
$$

Wherever $\delta$ is a scalar, $x_{i t}$ is $1 \times K$, and $\beta$ is $K \times 1$. The $\mu_{i t}$ go when a One-way disturbance component model $\mu_{i t}=\lambda_{i}+\varepsilon_{i t}$ the error term $\mu$ it is de-integrated into $\lambda_{i}$ and $\varepsilon_{i t}$ where $\lambda_{i}$ is the individual specific effect to cover the specific heterogeneity and $\varepsilon_{i t}$ is the error term. Timeoriented individualistic firm (unobserved basic results, $\left.\lambda_{i}\right)$. Present study used System GMM estimator of Blundell and Bond (1998) where level and differential calculations were combined into one equation. Sargent testing of excessive tool restrictions is valid, failing to throw away the hypothesis will mean that the tools used in the model are correct and the research model is well-defined. Serial correlation tests for the error term (Arellano \& Bond, 1991). We must reject $\mathrm{H} 0$ which means the absence of autocorrelation of first order (AR1) and do not rule out the non-appearance of serial connection of second order (AR2). Derives a similar derivation of this small sample bias and extends it to VCE (Robust) describing the twostep GMM estimation. The performance of the Sargan test does not imply that when the errors are heteroskedastic, the VCE (robust) definition is not ultimately provided to the state Sargan. After the definition of VCE (Robust) a healthy form of the Arellano-Bond test for autocorrelation was developed.

\section{Results discussion}

\subsection{Descriptive statistics}

The basic numbers of the variables used in the analysis are shown in Table 1. In all Pakistani manufacturing firms, the income based on shareholder investment is the mean value of ROA and ROE 3.02 and 4.78, respectively. The average financial leverage figure is 3.67 companies desiring to keep a balance for both current assets and liabilities, the average ER value is 4.26 percent, and the company's CFO is 7.01. The mean value of CCC is around 4.43. It indicates that Pakistani companies also own a very low volume of current assets and have less preference to hold receivable (account receivable / receivable notes), inventory stock and other few current assets. Where age has a mean value of 3.23, this is demonstrated in all industries of manufacturing. In this situation, the next consideration is extra suitable, examine the mean value of size is 9.71 , which means a very high relation between total assets and ROA.

\subsection{Correlation matrix results in the discussion}

Table 1 provides matrix for the variables in the Pearson correlation. CCC is strongly correlated with the dependent variables (ROA and ROE). In addition, the macroeconomic variable has a substantial relationship with ROA and ROE, and the model focused on firm performance accounting will support relevant, clear associations between macroeconomic variables. This result is consistent with Mohd and Siddiqui (2020), which found the exchange rate and ROA to be negative and substantial. The macroeconomic vector which is the exchange rate is greatly related to CCC dependent on outputs. Variance inflation analysis (VIF) was used to get good results for a multicollinearity issue between variables. The results showed that the total values are less than 10, and that in all models the highest VIF value is associated with the variance influence factor $=5.61,5.60$ and 4.96. Accordingly, the outcomes of the stipulated variables will not pose a multi-collinearity problem. The results shown in Table 2 give preliminary insights into how strong the impact of CCC on the performance of companies is. Further investigations have been used to obtain strong results for the association and to describe the results on hypotheses which can be observed in Table 2-3.

\subsection{Regression models result in discussion}

The primary model results reveal that CCC is negative and that it is significantly correlated with ROA and ROE. This observed outcome confirms the first hypothesis; similarly, these results are shown and supported by the correlation matrix. That means that, when companies normally reduce 


\begin{tabular}{|c|c|c|c|c|c|c|c|c|c|c|c|c|c|c|c|c|c|c|}
\hline \multirow{9}{*}{ 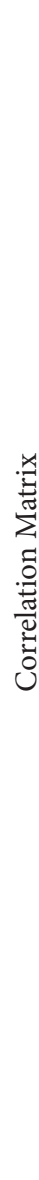 } & $\overrightarrow{\mid c}$ & & & & & & & & & & & & & & & هి & 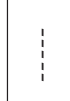 & \multirow{6}{*}{ 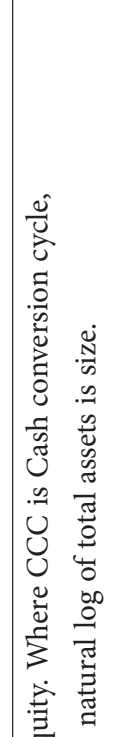 } \\
\hline & 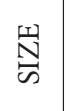 & & & & & & & & & & & & & ¿ & 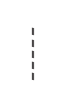 & 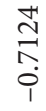 & $\begin{array}{l}8 \\
\vdots \\
\vdots \\
0\end{array}$ & \\
\hline & 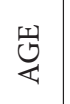 & & & & & & & & & & & ঃ & 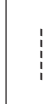 & 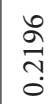 & $\begin{array}{l}\text { ¿े } \\
\stackrel{0}{0}\end{array}$ & $\begin{array}{l}\infty \\
\stackrel{2}{-1} \\
1\end{array}$ & $\begin{array}{l}8 \\
8 \\
\circ\end{array}$ & \\
\hline & 舀 & & & & & & & & & ¿ & 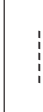 & ๙ิ & $\begin{array}{l}8 \\
\vdots \\
0 \\
0\end{array}$ & $\begin{array}{l}\text { Î } \\
\stackrel{5}{0} \\
\stackrel{0}{0}\end{array}$ & $\begin{array}{l}8 \\
8 \\
8 \\
\circ\end{array}$ & $\begin{array}{l}\underset{m}{\mathbb{N}} \\
\underset{i}{i} \\
\end{array}$ & $\begin{array}{l}8 \\
8 \\
8 \\
0\end{array}$ & \\
\hline & $\begin{array}{l}\text { O } \\
\text { U્ }\end{array}$ & & & & & & & $\begin{array}{l}8 \\
8 \\
8 \\
\end{array}$ & 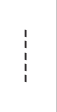 & $\begin{array}{l}10 \\
\stackrel{1}{0} \\
\infty \\
0 \\
0\end{array}$ & ఏ & $\begin{array}{l}\stackrel{2}{\circ} \\
\stackrel{2}{\circ}\end{array}$ & $\begin{array}{l}8 \\
\vdots \\
0 \\
0\end{array}$ & $\begin{array}{l}\hat{N} \\
2 \\
\alpha \\
\delta\end{array}$ & $\begin{array}{l}8 \\
8 \\
\circ \\
0\end{array}$ & $\begin{array}{l}2 \\
\alpha \\
o \\
0 \\
i\end{array}$ & $\begin{array}{l}8 \\
8 \\
\circ \\
0\end{array}$ & \\
\hline & U & & & & ஓ̊. & 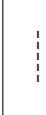 & & $\begin{array}{l}0 \\
0 \\
0 \\
0 \\
0 \\
\end{array}$ & $\begin{array}{l}8 \\
8 \\
0 \\
0\end{array}$ & \begin{tabular}{l}
$\infty$ \\
\multirow{1}{0}{} \\
$\stackrel{0}{0}$ \\
i
\end{tabular} & ఏ & $\begin{array}{l}0 \\
0 \\
0 \\
0 \\
\end{array}$ & $\begin{array}{l}\text { I } \\
\text { in } \\
0\end{array}$ & 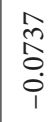 & \begin{tabular}{l}
8 \\
8 \\
\hdashline \\
\hdashline
\end{tabular} & $\begin{array}{l}\stackrel{0}{0} \\
\stackrel{0}{0} \\
0\end{array}$ & $\begin{array}{l}0 \\
\stackrel{7}{7} \\
\stackrel{m}{0}\end{array}$ & \\
\hline & 而 & & ڤ̊ & 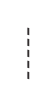 & $\begin{array}{l}\hat{R} \\
\hat{\sigma} \\
0 \\
i \\
i\end{array}$ & $\begin{array}{l}8 \\
\vdots \\
\circ\end{array}$ & & 'n & $\begin{array}{l}8 \\
8 \\
0 \\
0\end{array}$ & 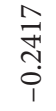 & ఏ & $\begin{array}{l}\text { ஜ̊ } \\
8 \\
0 \\
0\end{array}$ & $\begin{array}{l}0 \\
\stackrel{0}{0} \\
\infty \\
0\end{array}$ & 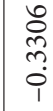 & \begin{tabular}{l}
8 \\
8 \\
\hdashline \\
\hdashline
\end{tabular} & ڤે & \begin{tabular}{l}
8 \\
8 \\
\hdashline \\
0
\end{tabular} & 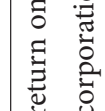 \\
\hline & $\underset{\mathscr{O}}{\overleftrightarrow{\prime}}$ & 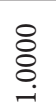 & 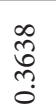 & 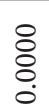 & $\begin{array}{l}\vec{p} \\
\text { +े } \\
0 \\
0\end{array}$ & $\begin{array}{l}0 \\
\circ \\
0\end{array}$ & & 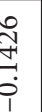 & \begin{tabular}{l}
8 \\
$\vdots$ \\
\hdashline
\end{tabular} & $\begin{array}{l}20 \\
8 \\
0 \\
0 \\
0\end{array}$ & ఏ & $\begin{array}{l}\text { ôे } \\
\text { o. } \\
0\end{array}$ & $\begin{array}{l}\infty \\
\tilde{O} \\
0 \\
0\end{array}$ & $\begin{array}{l}\hat{0} \\
0 \\
0 \\
0\end{array}$ & \begin{tabular}{l}
8 \\
\hdashline \\
\hdashline
\end{tabular} & $\begin{array}{l}\vec{\sigma} \\
\stackrel{7}{0}\end{array}$ & $\begin{array}{l}8 \\
\stackrel{0}{0} \\
\stackrel{0}{0}\end{array}$ & 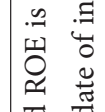 \\
\hline & 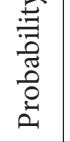 & 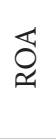 & \multicolumn{2}{|c|}{ 떵 } & \multicolumn{3}{|c|}{ ن } & \multicolumn{2}{|c|}{ 옹 } & \multicolumn{2}{|c|}{ 舀 } & \multicolumn{2}{|c|}{ 岁 } & \multicolumn{2}{|c|}{ 恣 } & \multicolumn{2}{|c|}{$\overrightarrow{\mid \vec{I}}$} & 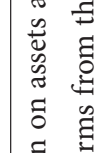 \\
\hline \multirow{7}{*}{ 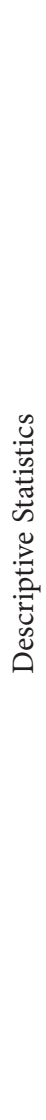 } & 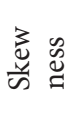 & $\begin{array}{l}\hat{N} \\
\hat{N} \\
\infty \\
0 \\
0\end{array}$ & 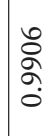 & $\begin{array}{l}\stackrel{0}{0} \\
\infty \\
\hat{0} \\
0\end{array}$ & $\begin{array}{l}\tilde{N} \\
\hat{n} \\
0 \\
0\end{array}$ & $\begin{array}{l}0 \\
\text { d } \\
\text { d } \\
c\end{array}$ & & 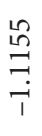 & $\mid \begin{array}{l}0 \\
2 \\
0 \\
10 \\
0 \\
0\end{array}$ & 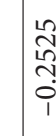 & & & & & & & & 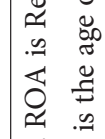 \\
\hline & $\begin{array}{l}\overrightarrow{\tilde{D}} \\
\dot{\vec{D}} \\
\dot{\tilde{n}}\end{array}$ & 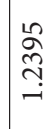 & $\begin{array}{l}\hat{N} \\
\infty \\
\stackrel{+}{+} \\
+1\end{array}$ & बे & $\begin{array}{l}\stackrel{0}{0} \\
\text { Sิ } \\
\stackrel{+}{+}\end{array}$ & ภ̊ & & $\begin{array}{l}\stackrel{R}{N} \\
\stackrel{0}{0}\end{array}$ & 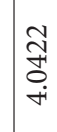 & \begin{tabular}{l}
8 \\
$\stackrel{8}{1}$ \\
\multirow{1}{1}{}
\end{tabular} & & & & & & & & \\
\hline & $\begin{array}{l}\text { 声 } \\
\text { 冝 }\end{array}$ & ஜ & ஓे & ठ & ¿े & ¿ & & $\begin{array}{l}8 \\
\vdots \\
\vdots \\
\circ\end{array}$ & 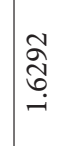 & ஓ & & & & & & & & 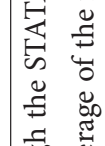 \\
\hline & $\begin{array}{l}\text { 志 } \\
\text { 离 } \\
\text { 艺 }\end{array}$ & 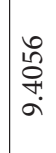 & $\begin{array}{l}0 \\
\infty \\
2 \\
0 \\
\stackrel{0}{0}\end{array}$ & $\begin{array}{l}0 \\
0 \\
0 \\
\tilde{ల} \\
0 \\
-1\end{array}$ & 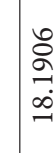 & ปู & & $\begin{array}{l}\text { बे } \\
\text { के } \\
\text { iे }\end{array}$ & 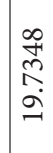 & \begin{tabular}{l}
0 \\
\multirow{2}{*}{} \\
\multirow{2}{+}{} \\
I
\end{tabular} & & & & & & & & 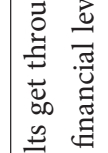 \\
\hline & 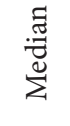 & $\begin{array}{l}\infty \\
\infty \\
\infty \\
\infty \\
i\end{array}$ & $\begin{array}{l}m \\
\hat{\sigma} \\
i \\
i\end{array}$ & $\begin{array}{l}0 \\
\text { రి } \\
+ \\
+ \\
+\end{array}$ & $\begin{array}{l}1 \\
\infty \\
\infty \\
\text { in }\end{array}$ & ง & & $\begin{array}{l}\vec{\infty} \\
\stackrel{\infty}{N} \\
\dot{n}\end{array}$ & $\begin{array}{l}0 \\
\stackrel{0}{0} \\
\stackrel{1}{r}\end{array}$ & ঙั & & & & & & & & 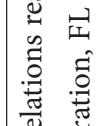 \\
\hline & $\stackrel{\text { है }}{\sum_{\Sigma}^{ \pm}}$ & $\begin{array}{l}\text { సે } \\
\text { ָे } \\
\dot{m}\end{array}$ & $\begin{array}{l}m \\
\infty \\
1 \\
+ \\
+i\end{array}$ & \begin{tabular}{l}
$\mathscr{N}$ \\
\multirow{H}{H}{} \\
+
\end{tabular} & 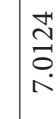 & 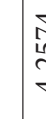 & & $\begin{array}{l}\hat{\mathrm{D}} \\
\text { ते } \\
\text { }\end{array}$ & $\begin{array}{l}\hat{n} \\
\hat{2} \\
a \\
\sigma\end{array}$ & $\begin{array}{l}\sqrt{n} \\
\hat{b} \\
\text { r. }\end{array}$ & & & & & & & & 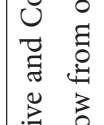 \\
\hline & & 离 & 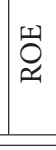 & U & 号 & A & & ड़ & 亚 & 로 & & & & & & & & 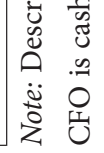 \\
\hline
\end{tabular}




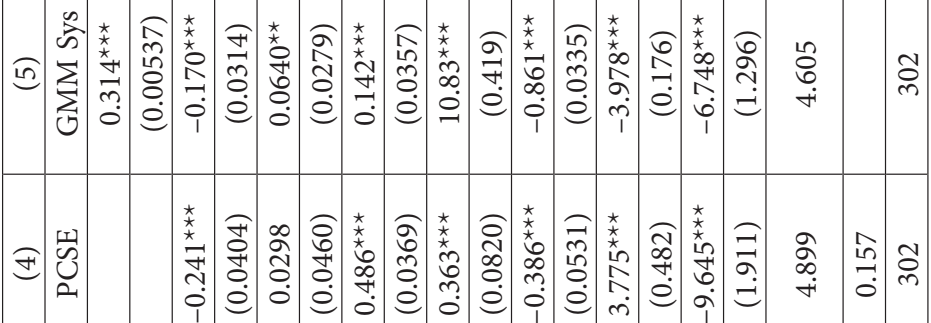

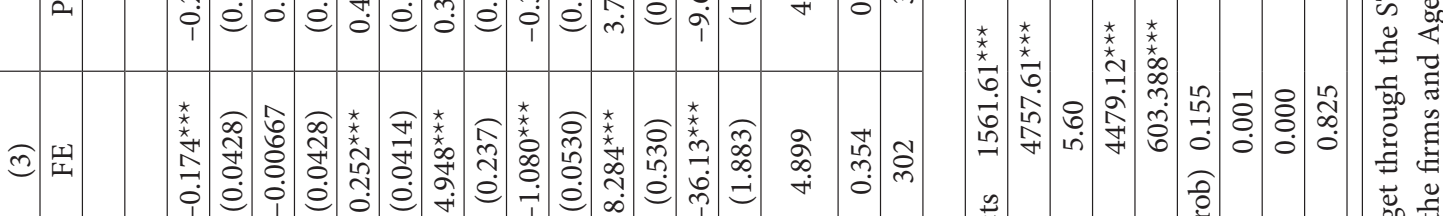

띵

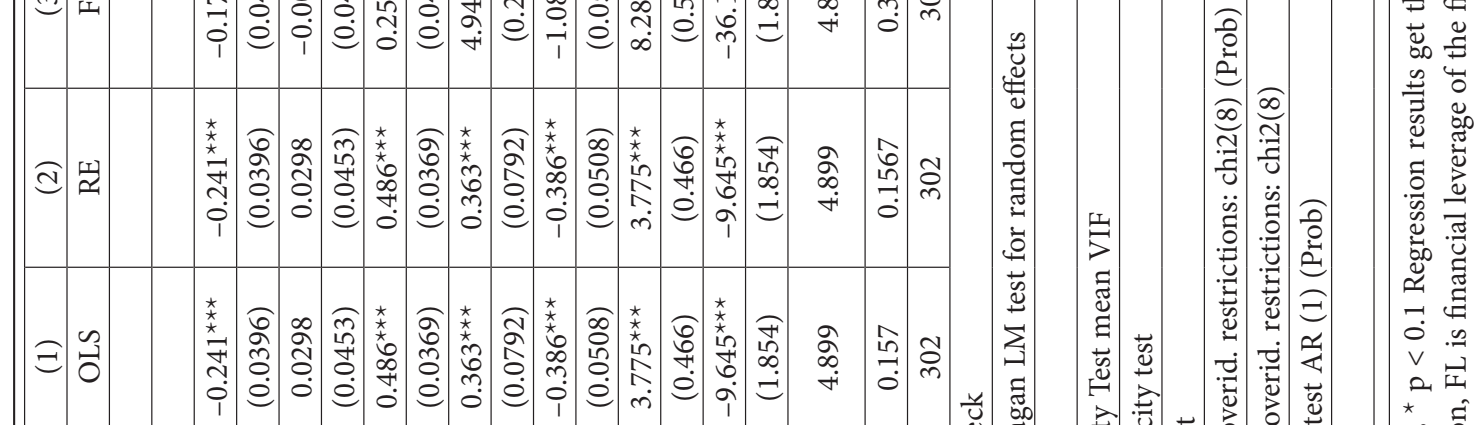

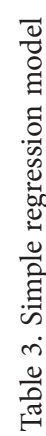

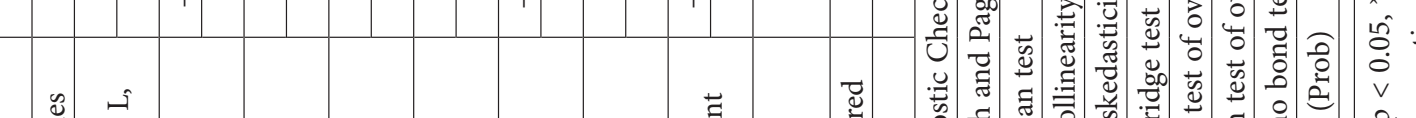

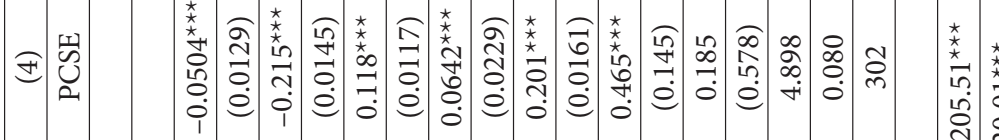

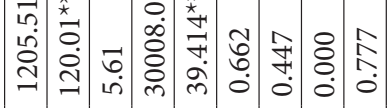

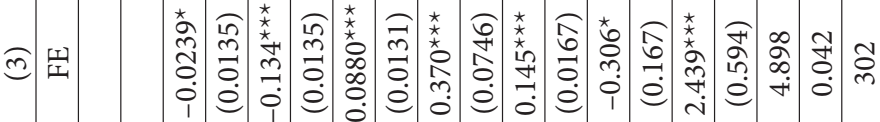

䓃

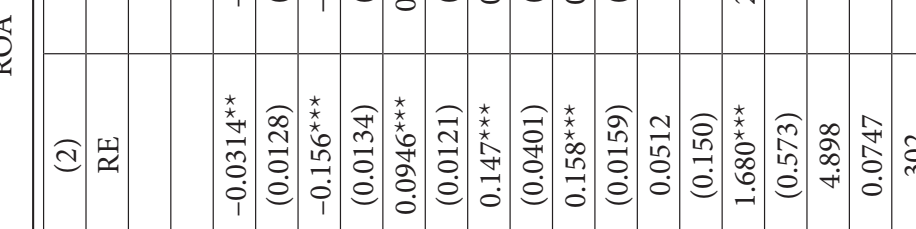

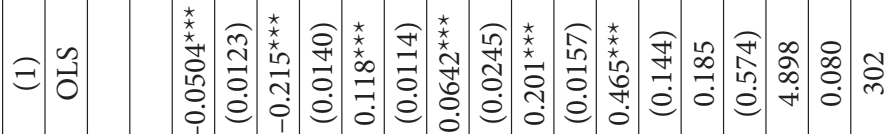

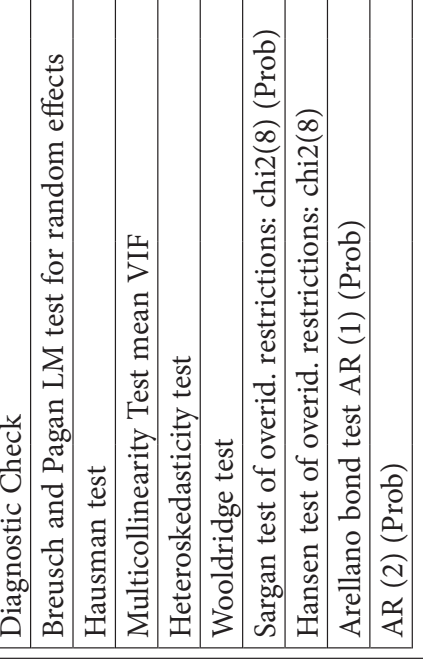

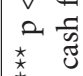

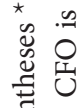

䒕

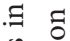

कั

동

密

$\sum_{0}^{0} 0$

تص

密荅

产言苍

它

을

吉总急

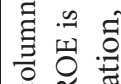

结

$\exists$ 范

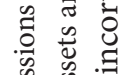

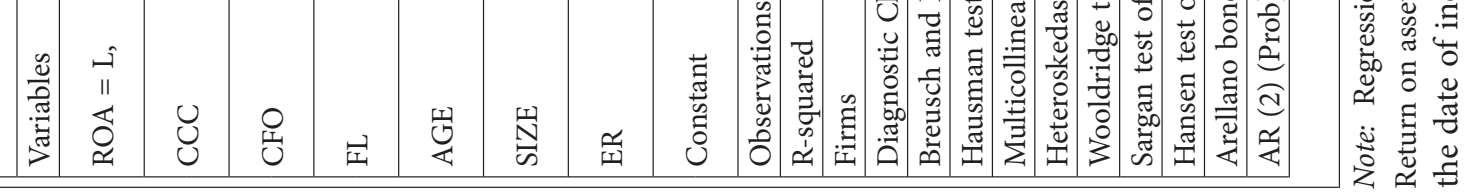

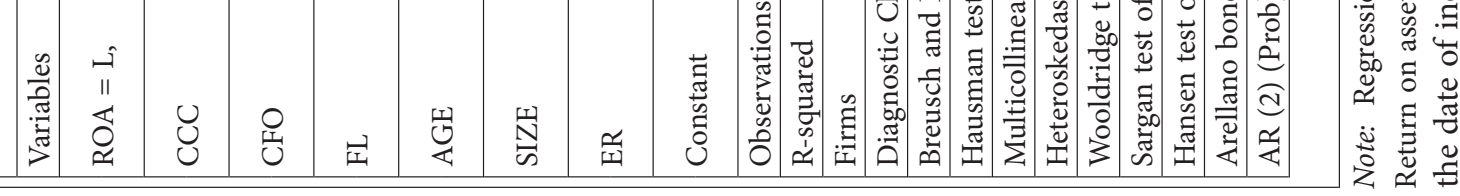


credit sales, the inventory of their products is linked up, notes and bills are distributed and strong for profitability. The judgment sets out the work of previous authors (Chang, 2018; Ren et al., 2019; Le, 2019; Boisjoly et al., 2020; Iqbal et al., 2020). In addition, Tsagem (2020) does not seem the second. In addition, the CFO has a negative relationship with ROA and a positive relationship with ROE, where size has a positive and significant association with ROA and ROE that confirms the result of the modelling process. In the case of big companies, this would attract new consumers and benefit to a greater extent from economies of scale. CFO's actual negative impact on ROA and ROE may explain the reflection that the outcome of bad debt is higher if credit sales are in a higher proportion of overall revenues; hence, lower productivity may be observed. The positive relationship in ROE, ROA, and financial leverage confirms a trend within ROE, ROA, and leverage. This association can be linked to the reality that while a company is extremely leveraged, it acquires notable cost of financing which later begins to reduce profitability. Based on the findings, the implications of the connection trend were supported by a real relationship between financial ROA and ROE, which retains the perception that more conservative strategies and the keeping of extra sums of current assets enhance market success. In addition, a positive association between ER and ROA confirmed, it indicates that the positive aspects of trade credit in high volatility situation with other companies (customers) beat the specific points of the stakes and have positive impacts on business performance. In addition, age is significantly associated with ROA, ROE which is incompatible with matrix correlation results. It showed that mature businesses can perform more comprehensively. Conclusively, the findings indicate that companies with good financial output tend to very strong fluctuations in job profits. Using the model's standard PCSE errors get robust and using the GMM model system helps us manage the problem of heteroskedasticity that existed in the FE model that was clearly exposed through the Heteroskedasticity test using Stata output results from httest 3 command. Woolridge test also defines the model as having a serial correlation problem. This serial correlation and heteroskedasticity problems are solved by PCSE in a static panel and covered by system GMM in the dynamic panel which was the basic purpose of using the GMM model.

It is clearly shown in Table 4. Non leaner regression model where the effect of ER (REER) on ROA is negative and significant. The Table 3rd and 4th, which proves the $3 \mathrm{rd}$ and 4 th hypotheses. The findings also determined by the matrix for the connection. Therefore, expenditure increases in high ER (REER) periods. The cost of finished goods also rises on the other round, and high ER (REER) generally has an adverse effect on market needs. But it is obvious that during periods of depreciation of the exchange rate, revenue growth shrinks more extra than expenditure. Unlike the $3 \mathrm{rd}$ table, the exchange rate in the FE and System GMM has a conflicting and important effect on ROA, but in the case of ROE it is positive in the case of FE but negative in the case of system GMM, which confirms the 5th and 6th hypotheses. It's obvious that a firm's performance is negatively influenced by ER (REER). The adversarial association between ER (REER) and ROE may result from Pakistan's high level of foreign financing (loan) from the IMF and the World Bank, which leads to an expansion in capital costs, followed by a decline in ROA, ROE. Based on the output Table 3, it is decided that the effect of ER (REER) on ROA is pleasant and prominent, which confirms the fifth hypothesis in which it arises. The optimistic relationship that ER has, across accounting-based success metrics, very in line with the findings of previous papers (Williams, 2018). It can be inferred that companies are able to take advantage of helpful financial situations and develop profitability. In addition, in performance situations, consumers can benefit from increasing per capita income, which would have a meaningful and assertive impact on demand and thus on the profitability of companies. But, unlike the previous model, CCC through ER (REER) does not have a significant impact on ROA and ROE that supports the sixth hypothesis. There is some doubt as to the decision regarding the association in CCC and ROE and ROA. The various adverse outcomes that affect the CCC-ROE and ROA association. (As a proxy of firm profitability performance) the indifference of that association could be revealed. Because of the significance of the element of interaction in the regression models, ER (REER) has no moderating results or any direct impact on the association that CCC with ROA and ROE, which gives no lining to the study's 5th and 6th hypotheses. The ER (REER) has an interaction impact of insignificance between CCC and ROA and ROE firm results. The exchange rate of Pakistan and the financial output of companies are considered to have an insignificant effect on Pakistan's CCC manufacturing policies, as seen in earlier investigations such as the report of Mohd and Siddiqui (2020).

\section{Robustness test and endogeneity problem}

Prior work has decided that the CCC and organization performance association (ROA, ROE) itself is a-present issue. Pooled least squares with standard error rule for panel correction are used to monitor possible endogeneity. Following past studies, the most common conductive factors, such as L.CCC Lyngstadaas and Berg (2016), are the first latency in CCC symptoms. Thus, CCC's first leg was employed in the models as a necessary variable. The linear model judgment shows all results are like those in nonlinear. Therefore, the selection of an accounting-based production that is ROA, ROE model, appears to have no endogenous issue and the fundamental first hypothesis is totally accepted. Admitting and checking for the issue of endogeneity in the model, ER (REER) does not impact the output assessed by CCC significantly. After using PCSE techniques to support this problem of endogeneity and the GMM system method to catch possible variable error, endogeneity (Smaoui \& Ghouma, 2020). 


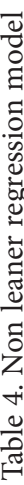

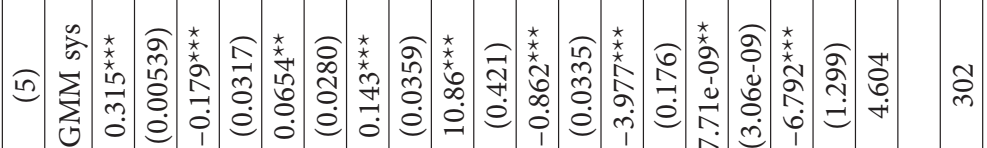

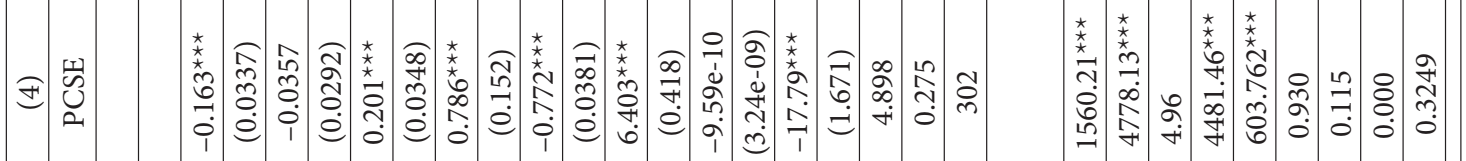

崖艺

क है

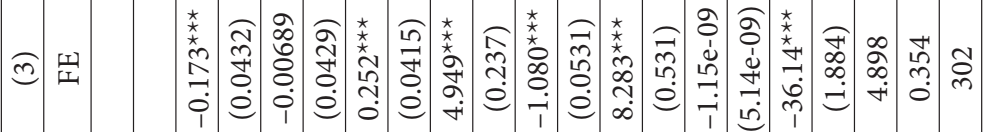

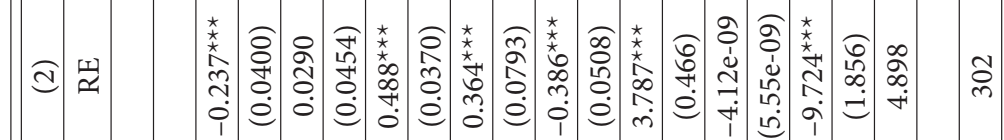

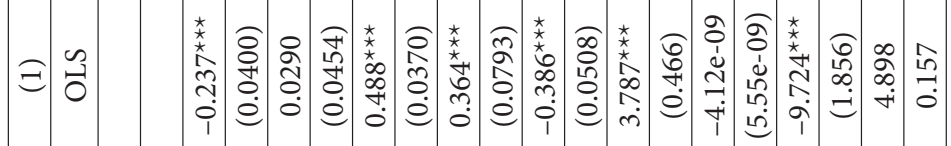

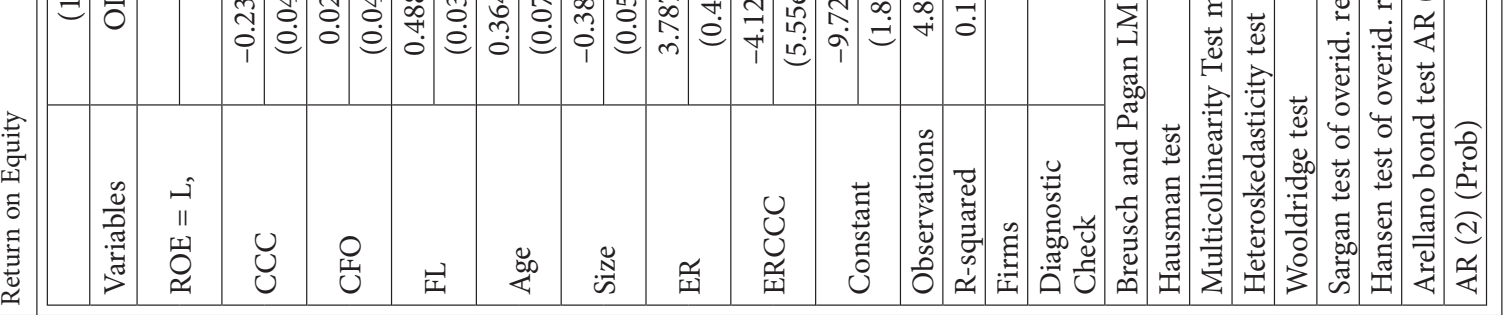

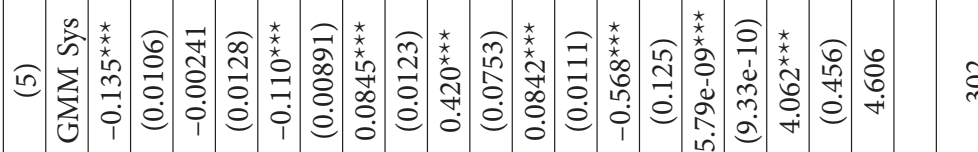

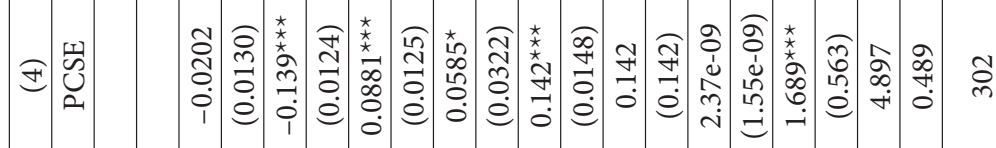

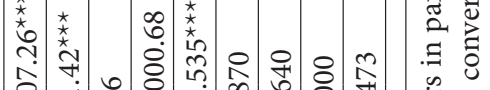

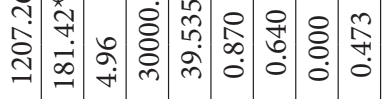

오월

范

늘

z)

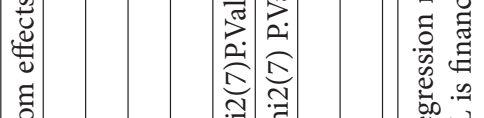

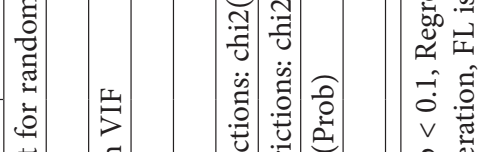

× \&

นิ

2,3

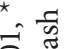

$\dot{0} \cdot \stackrel{0}{0}$

201

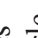

要

㐘

产 表

.

-

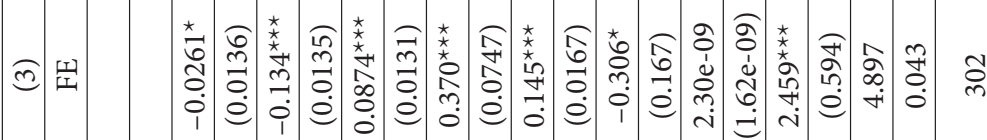

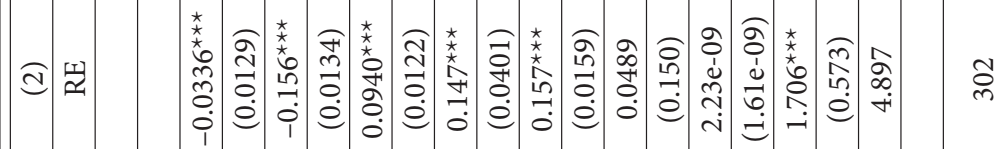

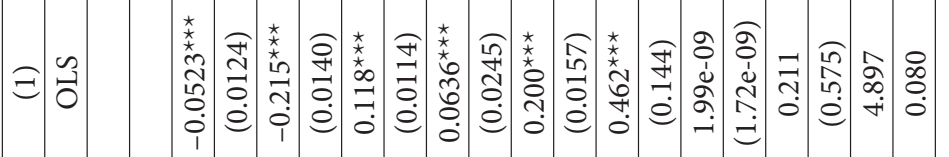

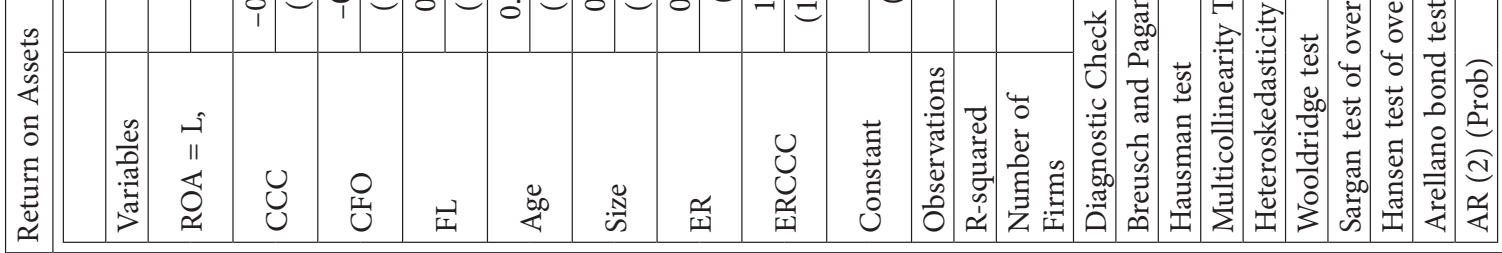

리츨

U

근

焉要恶

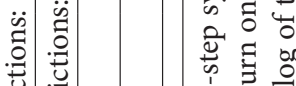

官密

苞惑

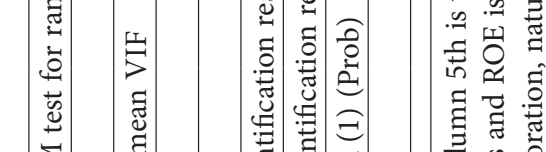

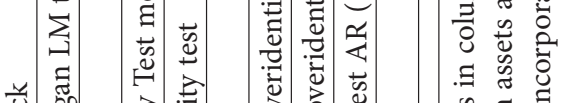

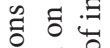

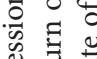




\section{Conclusions and future study}

This study is an interesting first step in the moderation of macroeconomic factors in the CCC-corporate performance relationship, which is the exchange rate (REER). A negative and significant correlation between CCC and ROE, ROA, was found, connecting a specific risk, and withdrawing several financial settlements. Therefore, the option of an aggressive strategy provides accountingbased performance growth. The credit given to customers should be limited to achieve this, inventories should be small, only to the degree that specifications are fulfilled, and bill payments should be extended. Furthermore, in the first investigation, CCC is negatively and substantially correlated with ROA and ROE, but when the endogeneity problem is tested, this correlation becomes much better than FE as a stronger CCC beta value. As a decision, CCC plans, which are correlated with short time periods, have a major effect on long-term results.

The fundamental role of economic factors has been investigated and the effects of ER (REER) on ROA and ROE have been found to be strongly positive. This relationship can be described as indicating that because they affect their contracts, skills, economic factors should be evaluated as macroeconomic conditions have a significant impact on accounting results, managers, more internal and controllable circumstances, staff, and business plans. As businesses perform at the highest level of ER (REER) in high-performing financial conditions, the gain of current performance is to attract more clients, get more customers, become aggressive and achieve more success. Aggressive, competitive tactics should be carried out. In addition, REER cautions businesses as they lift costs/prices and reduce the buying power of their consumers. To keep expenditures relatively high and to use motivational tactics (such as successful discounts) to help sales, however, managers must practice processes, such as cost control. REER was closely correlated with ROA, ROE, studied as a macroeconomic vector. Company managers are therefore advised to pay attention to REER vibrations, which have a direct impact on both small-term achievement and companies' value-creating capacity.

In addition, while macroeconomic factors (as moderating elements) are included in the models, others do not moderate the effect of the CCC on real performance. Pakistani company CCC, as addressed in Part 4, is expected to have a greater effect on the internal levels of companies, such as financial leverage, firm age and size, operating cash flow, and other related determinants, resulting in high intensity. Since this study takes place in an area where the REER is strong, these results should be carefully concluded by researchers. In addition, as a strong test, we do not have any inquiries about the endogeneity of the macroeconomic and business performance association, as no empirical findings have shown the possibility that endogeneity of this association is a dilemma, and it is not clear what dependent lag variables should be used to analyses it. In this sense, the presence of an endogeneity problem is sponsored by prospective researchers. Significant suggestions on theory and work are given by the results of this research. This report, which explores the connection between working capital management and accounting performance standards and the moderating position of macroeconomic variables in ER (REER), seems to enhance the writing of working capital management and provide an incentive for future researchers.

The influence of the CCC on various monetary achievements could be examined by future scholars. In addition, we inform prospective researchers that macroeconomic determinant may influence long-term performance symbols by evaluating the relationship within the ER (REER) macroeconomic determinants, not only modifying accounting indicators. The findings of this study also concentrate on important indications (decision-making managers should initially concentrate adjacent attention on different economic circumstances because the analysis results indicate that both the short and long-term routine of a business has a real and precise effect on the economic situation (ER). The conclusions of this report are based on this analysis. REER has a negative and meaningful relation with ROA and ROE in computing; the writers clarify that this can have a major impact due to REER's effect on the working capital system, which changes long-term output. Moreover, by increasing their cash exchange time, Pakistani corporate managers are specifically advised to increase their company competitiveness in the short run. Future researchers are strongly encouraged to estimate and relate the moderation of the exchange rate to data presented here in other economies that have several global situations (like economies with moderate REER rates). You should have an understanding here that macroeconomic variables are carried out against CCC and high performance. Furthermore, in determining the CCC report, researchers should move forward on this relationship and examine the moderating position of other macroeconomic indicators and expand the study of macroeconomic factors.

The Contribution and Significant of the Study is this is one of the very rare investigations being examined on the results. Macroeconomic variable ER (REER) as moderator between CCC and the company's ROA and ROE of different companies in Pakistan. Prior investigations based on their research, such as the food and beverage and textile industries, have studied the effect of microeconomic determinants on ROA and ROE (firms level components). When using the System GMM ER have negative and significant influence on firm performance, while it was positive and significant in static panel analysis. It provides information on this topic in different fields, including all manufacturing industries. The System GMM and PCSE Method applied on current analysis tools to draw inferences.

\section{Acknowledgements}

In this research paper, we would like to thank Dr. Asan Ali Golam Hassan for his valuable guidance. 


\section{Funding}

There was no funding for this study.

\section{Author contributions}

Conceptualization: Sarfraz Hussain, Abdul Quddus, Muhammad Rafiq, Asan Ali Golam Hassan.

Data curation: Sarfraz Hussain.

Formal analysis: Sarfraz Hussain.

Funding acquisition: Sarfraz Hussain, Abdul Quddus, Muhammad Rafiq.

Investigation: Sarfraz Hussain, Abdul Quddus, Muhammad Rafiq.

Methodology: Sarfraz Hussain.

Project administration: Sarfraz Hussain, Asan Ali Golam Hassan.

Resources: Sarfraz Hussain, Abdul Quddus, Muhammad Rafiq, Van Chien Nguyen.

Software: Sarfraz Hussain, Abdul Quddus.

Supervision: Asan Ali Golam Hassan.

Validation: Sarfraz Hussain, Abdul Quddus, Muhammad Rafiq.

Visualization: Abdul Quddus, Van Chien Nguyen, Muhammad Rafiq.

Writing - original draft: Sarfraz Hussain, Abdul Quddus, Muhammad Rafiq.

Writing - review \& editing: Sarfraz Hussain, Abdul Quddus.

\section{Disclosure statement}

The authors did not report any conflict of interest.

\section{References}

Alipour, M., Ghanbari, M., Jamshidinavid, B., \& Taherabadi, A. (2019). Does board independence moderate the relationship between environmental disclosure quality and performance? Evidence from static and dynamic panel data. Corporate Governance: The International Journal of Business in Society, 19(3), 580-610. https://doi.org/10.1108/CG-06-2018-0196

Arellano, M., \& Bond, S. (1991). Some tests of specification for panel data: Monte Carlo evidence and an application to employment equations. The Review of Economic Studies, 58(2), 277-297. https://doi.org/10.2307/2297968

Aron, A. Q., \& Maneja, J. M. (2020). Student's perception towards the appropriateness of phrase-picture-match-analysis as instructional material in teaching sampling techniques. $P E O$ PLE. International Journal of Social Sciences, 6(1). https://doi.org/10.20319/pijss.2020.61.349365

Aytac, B., Hoang, T. H. V., Lahiani, A., \& Michel, L. (2020). Working capital management and profitability of wine firms in France: an empirical analysis. International Journal of Entrepreneurship and Small Business, 41(3), 368-396. https://doi.org/10.1504/IJESB.2020.110803

Blundell, R., \& Bond, S. (1998). Initial conditions and moment restrictions in dynamic panel data models. Journal of Econometrics, 87(1), 115-143.

https://doi.org/10.1016/S0304-4076(98)00009-8
Boisjoly, R. P., Conine, T. E., \& McDonald, M. B. (2020). Working capital management: Financial and valuation impacts. Journal of Business Research, 108(November 2018), 1-8. https://doi.org/10.1016/j.jbusres.2019.09.025

Chang, C. C. (2018). Cash conversion cycle and corporate performance: Global evidence. International Review of Economics and Finance, 56(December 2017), 568-581. https://doi.org/10.1016/j.iref.2017.12.014

Cheng, F., Chiao, C., Fang, Z., Wang, C., \& Yao, S. (2019). Raising short-term debt for long-term investment and stock price crash risk: Evidence from China. Finance Research Letters, 33, 101200. https://doi.org/10.1016/j.frl.2019.05.018

Dalci, I., \& Ozyapici, H. (2018). Working capital management policy in health care: The effect of leverage. Health Policy, 122(11), 1266-1272.

https://doi.org/10.1016/j.healthpol.2018.09.012

Doan, T., \& Bui, T. (2020). Nonlinear impact of supply chain finance on the performance of seafood firms: A case study from Vietnam. Uncertain Supply Chain Management, 8(2), 267-272. https://doi.org/10.5267/j.uscm.2020.1.001

Ha, D. T. T., \& Hoang, N. T. (2020). Exchange rate regime and economic growth in Asia: Convergence or divergence. Journal of Risk and Financial Management, 13(1), 9.

https://doi.org/10.3390/jrfm13010009

Högerle, B., Charifzadeh, M., Ferencz, M., \& Kostin, K. B. (2020). The development of working capital management and its impact on profitability and shareholder value: evidence from Germany. Strategic Management, 25(2), 27-39. https://doi.org/10.5937/StraMan2002027H

Hong, J. (2020). The financing of alliance entrepreneurship. Journal of Business Venturing, 35(1), 105916. https://doi.org/10.1016/j.jbusvent.2018.12.002

Hossain, T. (2020). The effect of working capital management on profitability. International Journal of Research in Business and Social Science (2147-4478), 9(6), 114-122. https://doi.org/10.20525/ijrbs.v9i6.872

Iqbal, U., Gan, C., \& Nadeem, M. (2020). Economic policy uncertainty and firm performance. Applied Economics Letters, 27(10), 765-770. https://doi.org/10.1080/13504851.2019.1645272

Khan, M. M., Shagor, M. I. H., Kalam, A., \& Ahmed, M. S. (2020). Working capital management and firm profitability in the textile industry of Bangladesh. International Journal of Science and Business, 4(7), 118-127.

Kumaraswamy, S. (2016). Impact of working capital on financial performance of gulf cooperation council firms. International Journal of Economics and Financial Issues, 6(3), 1136-1143.

Le, B. (2019). Working capital management and firm's valuation, profitability and risk: Evidence from a developing market. International Journal of Managerial Finance, 15(2), 191-204. https://doi.org/10.1108/IJMF-01-2018-0012

Lin, Q., \& Lin, X. (2020). Cash conversion cycle and aggregate stock returns. Journal of Financial Markets, 52, 100560. https://doi.org/10.1016/j.finmar.2020.100560

Mohd, A. S., \& Siddiqui, D. A. (2020). Effect of macroeconomic factors on firms ROA: A comparative sectorial analysis from Pakistan. International Journal of Publication and Social Studies, 5(1), 1-17. https://doi.org/10.18488/journal.135.2020.51.1.17

Moussa, A. A. (2019). Determinants of working capital behavior: evidence from Egypt. International Journal of Managerial Finance, 15(1), 39-61. https://doi.org/10.1108/IJMF-09-2017-0219 
Onchangwa, G. A. (2019). Effects of working capital management on financial distress of non-financial firms listed at the Nairobi securities exchange market [Doctoral dissertation, JKUATCOHRED].

Oseifuah, E. (2016). Determinants of working capital requirements: evidence from selected non-financial firms listed on the Johannesburg securities exchange. The Journal of Accounting and Management, 6(1).

Ren, T., Liu, N., Yang, H., Xiao, Y., \& Hu, Y. (2019). Working capital management and firm performance in China. Asian Review of Accounting, 27(4), 546-562.

https://doi.org/10.1108/ARA-04-2018-0099

Sawarni, K. S., Narayanasamy, S., \& Ayyalusamy, K. (2020). Working capital management, firm performance, and nature of business. International Journal of Productivity and Performance Management, 70(1). https://doi.org/10.1108/IJPPM-10-2019-0468

Seth, H., Chadha, S., Ruparel, N., Arora, P. K., \& Sharma, S. K. (2020). Assessing working capital management efficiency of Indian manufacturing exporters. Managerial Finance, 46(8). https://doi.org/10.1108/MF-02-2019-0076

Shah, S. T. H. (2019). Impact of working capital management on profitability of pharmaceutical and chemical companies: a comparative study of Pakistan and India. Journal of Managerial Sciences, 13(1).
Smaoui, H., \& Ghouma, H. (2020). Sukuk market development and Islamic banks' capital ratios. Research in International Business and Finance, 51, 101064.

https://doi.org/10.1016/j.ribaf.2019.101064

Tsagem, M. M. (2020). Cash conversion cycle and profitability of Nigerian small and medium-sized entities: An empirical analysis. International Journal of Banking and Finance, 13(1), 49-69.

Ujah, N. U., Tarkom, A., \& Okafor, C. E. (2020). Working capital management and managerial talent. International Journal of Managerial Finance, 17(3). https://doi.org/10.1108/IJMF-12-2019-0481

Widyastuti, M., Oetomo, H. W., \& Riduwan, A. (2017). Working capital and macroeconomic variables as value creation in Indonesian textile companies. International Journal of Business and Finance Management Research, 5, 7-16.

Williams, H. T. (2018). An empirical investigation of the impact of exchange rate fluctuations on the performance of selected listed firms in Nigeria. Journal of Business Management and Economic Research, 2(3), 1-10. https://doi.org/10.29226/TR1001.2018.22

Zeidan, R., \& Shapir, O. M. (2017). Cash conversion cycle and value-enhancing operations: Theory and evidence for a free lunch. Journal of Corporate Finance, 45, 203-219. https://doi.org/10.1016/j.jcorpfin.2017.04.014 